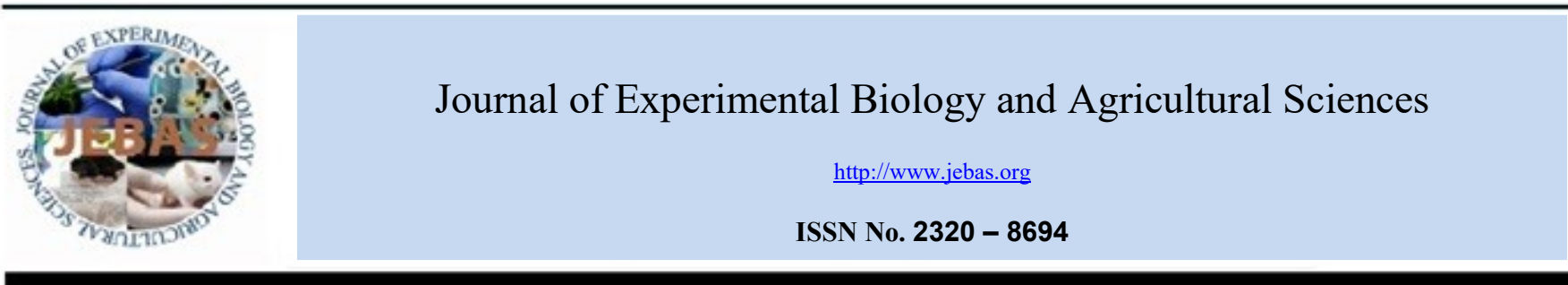

\title{
OPTIMIZATION OF MINERAL SUPPLEMENTS FOR THE PRODUCTION OF ALPHA AMYLASE FROM RICE BRAN USING Aspergillus Oryzae THROUGH SUBMERGED FERMENTATION
}

\section{Muralikandhan Kamaraj $^{1 *}$, Dhanasekaran Subramaniam ${ }^{2}$}

\begin{abstract}
${ }^{1}$ Bioprocess Laboratory, Department of Chemical Engineering, Faculty of Engineering and Technology, Annamalai University, Annamalai Nagar - 608 002, Tamil Nadu, India

${ }^{2}$ Mass Transfer laboratory, Department of Chemical Engineering, Faculty of Engineering and Technology, Annamalai University, Annamalai Nagar - 608 002, Tamil Nadu, India
\end{abstract}

Received - April 30, 2020; Revision - June 25, 2020; Accepted - August 06, 2020

Available Online - August 25, 2020

DOI: http://dx.doi.org/10.18006/2020.8(4).456.468

\section{KEYWORDS}

Alpha amylase

Rice Bran

Aspergillus oryzae

Submerged fermentation

Mineral supplements

Optimization

Plackett-Burman Design

\begin{abstract}
This study is aimed to investigate the optimum level of mineral supplements for the maximum production of fermentative $\alpha$-amylase by using cheap substrate rice bran. The fungal strain Aspergillus oryzae MTCC8624 is used to investigate the $\alpha$-amylase production capability. The culture is maintained on potato dextrose agar (PDA) and sub-cultured at an interval of three months. The culture is initially screened for amylase production by starch agar plate assay on standard media. The report concludes that the optimization of mineral supplements for the fermentative $\alpha$-amylase production and its suitability for a large-scale production using cheap and easily available substrate rice bran. The significant media components identified by Plackett-Burman design are $\mathrm{KH} 2 \mathrm{PO} 4=2.69 \mathrm{~g} / \mathrm{L} ; \mathrm{MgSO} 4=1.70 \mathrm{~g} / \mathrm{L} ; \mathrm{CaCl} 2=$ $0.53 \mathrm{~g} / \mathrm{L} ; \mathrm{FeSO} 4=0.5 \mathrm{~g} / \mathrm{L}$ and $(\mathrm{NH} 4) 2 \mathrm{SO} 4=4.95 \mathrm{~g} / \mathrm{L}$ for Rice Bran
\end{abstract}

* Corresponding author

E-mail: muralikandhan1976@gmail.com (Muralikandhan Kamaraj)

Peer review under responsibility of Journal of Experimental Biology and Agricultural Sciences.

Production and Hosting by Horizon Publisher India [HPI] (http://www.horizonpublisherindia.in/).

All rights reserved.
All the articles published by Journal of Experimental Biology and Agricultural Sciences are licensed under a Creative Commons Attribution-NonCommercial 4.0 International License Based on a work at www.jebas.org.

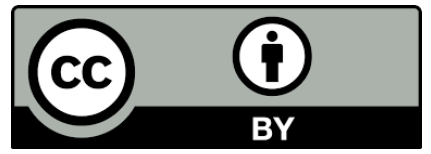




\section{Introduction}

Application of amylase enzyme is versatile and its demand in the various industries such as food, fermentation, textile, paper, detergent, pharmaceutical, and sugar are paramount (Asrat \& Girma, 2018). Further, the economic and technological significance forced to pay great attention to the production of amylase enzyme. Its role in the hydrolysis of $\alpha$-D-(1,4) glycosidic linkage in starch components and related polysaccharides to release maltose and disaccharide is the main reason for the continuous intensive research (Shah et al., 2014; Avwioroko \& Tonukari, 2015; Bharathiraja et al., 2016; Subash et al., 2017; Asrat \& Girma, 2018). Selection of substrate, the potential of microorganism, methods of cultivation, cell growth, nutrient requirement, metal ions, $\mathrm{pH}$, temperature, incubation period and thermostability are the main factors which directly influence the rate of amylase production (Pankaj et al., 2015). The utilization of agriculture waste is a promising one for the sustainable production of amylase. Cheaper cost and abundant availability are the supporting thoughts for the above statement (Bharathiraja et al., 2016). Due to the increasing demand for alphaamylase in various industries, there is enormous interest in developing enzymes with better properties such as raw starch degrading amylases suitable for industrial applications and there cost-effective production techniques (Konsula \& LiakopoulouKyriakides, 2004; Shivaramakrishnam et al., 2006). The selection of appropriate carbon and nitrogen sources or other nutrients is one of the most critical stages in the development of an efficient and economic process (Jiby et al., 2016). Further, Asrat \& Girma (2018) investigated the potential of newly isolated strain Aspergillus niger FAB-211using fruit peel wastes for the production of amylase. The report infers the maximum amylase activity of $1,241 \mathrm{U} / \mathrm{ml}$ at a $\mathrm{pH}$ of 6.0 and temperature at $45^{\circ}$. Further, Elmansy et al. (2018) studied the effect of various fermentation conditions on $\alpha$-amylase production through shake-flask culture Bacillus sp. NRC22017 and the maximum yield of $\alpha$-amylase is inferred to be $15.15 \pm 0.47 \mathrm{U} / \mathrm{ml}$ at a $\mathrm{pH}$ of 6.0 with an inoculum size of $500 \mu \mathrm{l}$ at $45^{\circ} \mathrm{C}$ and anaerobic incubation period of $72 \mathrm{~h}$. Physical factors that are affecting the production of the $\alpha$-amylase from a newly isolated Bacillus sp. M10 strain. lus sp. M-10 namely temperature, $\mathrm{pH}$, aeration, inoculum size, and inoculum age are optimized by Demirkan et al. (2017). Among the important factors, $37^{\circ} \mathrm{C}$ temperature, $\mathrm{pH} 7.0,150 \mathrm{rpm}$ for aeration, $2.5 \%(\mathrm{v} / \mathrm{v})$ inoculation size and 2 days for inoculation age are found to be the optimum rate for maximum $\alpha$-amylase production of $30 \mathrm{U} / \mathrm{mL}$ at the hour of 48 . Pathania et al., (2017) optimized the process variables included $\mathrm{pH}$, temperature, inoculum size, incubation days and substrate concentration for production of amylase by $B$. amyloliquifaciens SH8 using response surface methodology and achieved the maximum amylase activity of 16.07 $\mathrm{IU} / \mathrm{ml}$ at the optimum condition of $\mathrm{pH} 5$, temperature $45^{\circ} \mathrm{C}$, inoculum size $5 \%$, incubation day of 5 , and substrate concentration of $0.60 \%$. Similarly, Jiby et al. (2016) tested the activity of $\alpha$ - amylase from $A$. niger utilizing coconut water, tapioca water, rice water, and white yam. The maximum activity of $\alpha$-amylase is recorded as $0.29 \times 10^{-3} \mu$ moles/sec after 7 days of submerged fermentation on white Yam water at $\mathrm{pH} 7.0$ and $28^{\circ} \mathrm{C}$. Among the three medium, rice water recorded as second $\left(0.09 \times 10^{-3}\right.$ $\mu \mathrm{moles} / \mathrm{sec})$ and tapioca water $\left(0.06 \times 10^{-3} \mu \mathrm{moles} / \mathrm{sec}\right)$ as third position. Vimal et al. (2015) identified as B.amyloliquefaciens KCP2 using 16S rDNA gene sequencing data yielded the maximum amylase activity of $63.12 \mathrm{U} / \mathrm{gds}$. Similarly, Ahmed et al. (2015) optimized the experimental parameters for alpha-amylase production by $A$. fumigatusin submerged fermentation, these researchers used sunflower waste, cotton stalk, rice husk, date syrup, and molasses are tested as carbon source. The maximum production of $\alpha$-amylase is found to be $7.01 \mathrm{U} / \mathrm{mL}$ by $A$. fumigates are $72 \mathrm{~h}$ of incubation period at initial $\mathrm{pH} 5.5$, temperature $35^{\circ} \mathrm{C}$, inoculum size of $6 \times 10^{6}$ conidia in $50 \mathrm{~mL}$ of culture medium and agitation rate of $150 \mathrm{rev} / \mathrm{min}$. Shah et al. (2014) isolates a total of 17 fungal cultures from soil samples. Out of which IP31, A.oryzae, exhibited good amylolytic enzymes production. After parametric optimization maximum amylolytic activity was observed, when $\mathrm{pH}$ of the mineral salt medium was 7.0, incubation temperature of $45^{\circ} \mathrm{C}$, after incubation of $72 \mathrm{hrs}$ by using $50 \mathrm{~mL}$ of starchy wastewater as sole carbon source with 5 discs of $A$. oryzae. After studying the kinetic properties of $\alpha$-amylase, its maximum activity was found at $\mathrm{pH} 6$, the temperature of $50^{\circ} \mathrm{C}$, with $1.5 \%$ of substrate concentration. The Vmax and $\mathrm{Km}$ value was $37.037 \mathrm{IU} / \mathrm{mL}$ and $1.4 \mathrm{mg} / \mathrm{mL}$ respectively for $\alpha$-endocellulase. Submerged fermentation has been defined as fermentation in the presence of excess water. Almost all the large-scale enzymeproducing facilities are using the proven technology of submerged fermentation due to better monitoring and ease of handling (Singhania, 2011). It is the preferred technology for industrial enzyme production due to ease of handling at large-scale when compared to SSF. Conventional fermenters for submerged fermentation technology are properly advanced and offer online manage over several parameters together with $\mathrm{pH}$, temperature, dissolved oxygen, and froth formation with easy mass transfer and heat removal. These benefits make submerged fermentation technology superior to solid-state. It is widely conformist for industrial metabolites production. The choice of an appropriate condition for the substrate is a key aspect of submerged fermentation. It depends on various factors, including cost, availability, particle size, and moisture content. This screening process involves, avoiding the formation of several by-products and the substrate of choice being the one that not only serves as the best nutrient source but also acts as the best support for cell growth (Rajagopalan \& Krishnan, 2008). The medium in submerged fermentation is liquid, which remains in contact with the microorganisms (Singhania et al., 2015). With this few introductions, this investigation is aimed to optimize the mineral supplements for the production of alpha-amylase from A.oryzae using rice bran through submerged fermentation. 


\section{Materials and Methods}

\subsection{Microorganism and its Maintenance}

The strain of A.oryzae MTCC-8624 used in this investigation was obtained from MTCC, Institute of Microbial Technology (IMTECH), Chandigarh, India. The culture is maintained on potato dextrose agar (PDA) and sub-cultured at an interval of three months (Ellaiah et al., 2002). The culture is initially screened for amylase production by starch agar plate assay on standard media. The inoculated plates, containing media, supplemented with starch is stained with Gram's iodine reagent, after $72 \mathrm{hr}$ of incubation. The plates are then flooded with iodine solution for 15 minutes and washed with warm water to remove the excess colour (Mabel et al., 2006).

\subsection{Inoculum Preparation}

The strain is sub-cultured on PDA slants and incubated for $72 \mathrm{hr}$ at a temperature of $25^{\circ} \mathrm{C}$. After the incubation period, the spore suspensions are prepared by adding $10 \mathrm{ml}$ of sterile water to the PDA slant containing sporulated slant cultures. The spores on the surface of the medium were dislodged using inoculation needle under aseptic conditions. The spore suspensions are filtered using sterile muslin cloth into sterile flasks. The filtered spore suspension is transferred into $250 \mathrm{ml}$ Erlenmeyer flask containing $100 \mathrm{ml}$ of potato dextrose broth and incubated for three days at $25^{\circ} \mathrm{C}$. Appropriate volumes of inoculums $(\% \mathrm{v} / \mathrm{v})$ are used to inoculate the production medium (Tanyildizi et al., 2005).

\subsection{Fermentation Medium}

In this investigation, rice bran is utilized as a substrate. It is collected from nearby areas of Chidambaram, Tamil Nadu, India. Since this agricultural by-product is not available in completely dried form, it is necessary to dry this substrate prior to use them in the fermentation process. In the present study, the substrate is dried by keeping them in the oven at $80^{\circ} \mathrm{C}$ for $12 \mathrm{hr}$. After drying, the substrates are powdered in a laboratory grinder and sieved using a $40 \mathrm{~mm}$ sieve. An adequate amount of the powdered substrate is mixed with $100 \mathrm{ml}$ of the corresponding mineral salt media in a $250 \mathrm{ml}$ Erlenmeyer flask. After adjusting the $\mathrm{pH}$, the contents of the flask were sterilized in an autoclave at $121^{\circ} \mathrm{C}$ and 15 psi pressure for 15 minutes. Appropriate volumes of inoculums are added to the flasks after cooling it down to room temperature. All the experiments for media optimization were carried out with a substrate concentration of $20 \mathrm{~g} / \mathrm{L}$, inoculum size of $5 \%(\mathrm{v} / \mathrm{v})$, and fermentation time of $72 \mathrm{hr}$. The $\mathrm{pH}$ and temperature are maintained at 5 and $25^{\circ} \mathrm{C}$ respectively (Sarra et al., 1993).

\subsection{Extraction of amylase from the fermentation medium}

At the end of the fermentation period, contents of the flask are filtered using a Whatman No.44 filter paper followed by filtration through a muslin cloth. The filtrate is then centrifuged at 10,000 rpm for $10 \mathrm{~min}$ and the supernatant was used as the source of enzyme for assay (Ahuja et al., 2004).

\subsection{Assay of amylase}

Assay system for amylase activity is carried out by measuring the amount of reducing sugar according to DNS method (Fogarty, 1983). Amylase activity is determined by incubating a mixture of $1 \mathrm{ml}$ of the aliquot of each enzyme source and $1 \%$ soluble starch dissolved in $0.1 \mathrm{M}$ phosphate buffer, at $\mathrm{pH} 7$, at $55^{\circ} \mathrm{C}$ for $15 \mathrm{~min}$. The reaction is arrested by adding $1 \mathrm{ml}$ of 3,5 DNS Acid followed by 10 minutes boiling. The final volume is made up of $12 \mathrm{ml}$ with distilled water and the reducing sugar released was measured at $540 \mathrm{~nm}$. Reducing sugar (Glucose or maltose) concentration is determined from a standard curve under the same condition using glucose. Figure 1 is used to represent the calibration curve for glucose concentration using Bio-spectrophotometer (Ellaiah et al., 2002; Mabel et al., 2006).

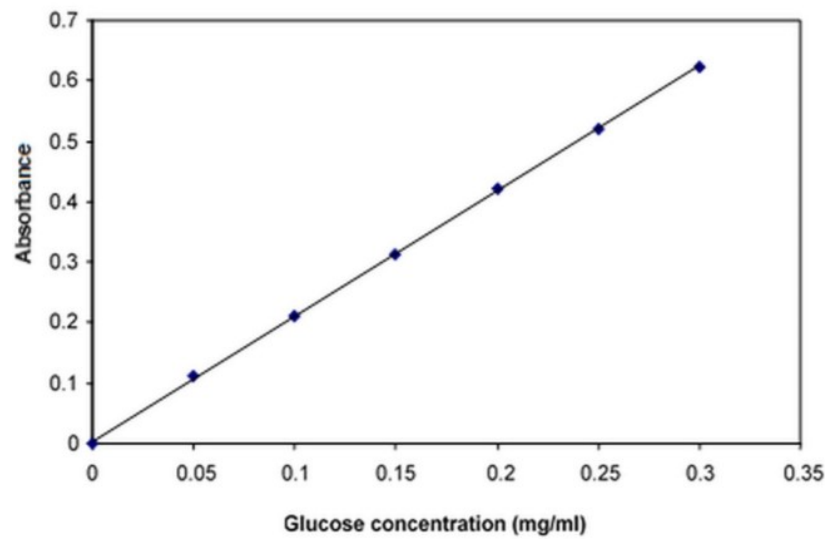

Figure 1 Calibration chart for glucose concentration using Biospectrophotometer

\section{Results and Discussion}

\subsection{Screening of media components for Aspergillus oryzae}

Fifteen variables were screened in twenty trials, each variable being a media constituent. The medium constituents used for $A$. oryzae $\mathrm{MTCC}-8624$ are $\mathrm{KH}_{2} \mathrm{PO}_{4}(\mathrm{~A}),\left(\mathrm{NH}_{4}\right)_{2} \mathrm{SO}_{4}(\mathrm{~B}), \mathrm{KCl}(\mathrm{C})$, $\mathrm{MgSO}_{4}(\mathrm{D}), \mathrm{CaCl}_{2}(\mathrm{E})$, Urea(F), $\mathrm{FeSO}_{4}(\mathrm{G}), \mathrm{ZnCl}_{2}(\mathrm{H}), \mathrm{NH}_{4} \mathrm{NO}_{3}(\mathrm{~J})$, $\mathrm{NaCl}(\mathrm{K}), \mathrm{MnSO}_{4}(\mathrm{~L}), \mathrm{K}_{2} \mathrm{HPO}_{4}(\mathrm{M}), \mathrm{CoCl}_{2}(\mathrm{~N}), \mathrm{NaNO}_{3}(\mathrm{O})$ and $\mathrm{FeCl}_{3}(\mathrm{P})$. Two level design ( -1 indicates the lower level and +1 indicates the higher level) are generated for fifteen variables with one replicate. The coded and actual values of the variables are shown in Table 1. Table 2 shows Plackett-Burman design for conducting 20 trials and the corresponding amylase production was noted. The effect of the variables and their significance on 
Table 1 Variables screened in Plackett-Burman design for amylase activity using A. oryzaeMTCC-8624

\begin{tabular}{|c|c|c|}
\hline Variables & $\begin{array}{c}\text { Low level } \\
(-) \text { values }(\mathrm{g} / \mathrm{L})\end{array}$ & $\begin{array}{c}\text { High level } \\
(+) \text { values }(g / L)\end{array}$ \\
\hline $\mathrm{KH}_{2} \mathrm{PO}_{4}$ & 1 & 5 \\
\hline $\mathrm{MgSO}_{4}$ & 1 & 3 \\
\hline Peptone & 1 & 10 \\
\hline Yeast extract & 2 & 8 \\
\hline $\mathrm{FeSO}_{4}$ & 2 & 5 \\
\hline $\mathrm{CaCl}_{2}$ & 0.2 & 2 \\
\hline $\mathrm{NaCl}$ & 1 & 3 \\
\hline $\mathrm{NaNO}_{3}$ & 0.5 & 1.5 \\
\hline Urea & 0.5 & 5 \\
\hline $\mathrm{MnSO}_{4}$ & 0.1 & 0.9 \\
\hline$\left(\mathrm{NH}_{4}\right)_{2} \mathrm{SO}_{4}$ & 1 & 5 \\
\hline $\mathrm{CoCl}$ & 0.005 & 0.5 \\
\hline $\mathrm{ZnSO}_{4}$ & 1 & 5 \\
\hline $\mathrm{ZnCl}_{2}$ & 0.1 & 1 \\
\hline $\mathrm{KCl}$ & 1 & 7 \\
\hline
\end{tabular}

Table 2 Plackett-Burman experimental design matrix for screening of important variables for A. oryzae MTCC-8624 utilizing rice bran

\begin{tabular}{|c|c|c|c|c|c|c|c|c|c|c|c|c|c|c|c|c|c|}
\hline \multirow{2}{*}{ Runs } & \multirow{2}{*}{ A } & \multirow[t]{2}{*}{$\mathrm{B}$} & \multirow{2}{*}{$\mathrm{C}$} & \multirow{2}{*}{$\mathrm{D}$} & \multirow{2}{*}{$\mathrm{E}$} & \multirow[t]{2}{*}{$\mathrm{F}$} & \multirow{2}{*}{$\mathrm{G}$} & \multirow[t]{2}{*}{$\mathrm{H}$} & \multirow[t]{2}{*}{$\mathrm{J}$} & \multirow{2}{*}{ K } & \multirow[t]{2}{*}{ L } & \multirow{2}{*}{$\mathrm{M}$} & \multirow[t]{2}{*}{$\mathrm{N}$} & \multirow[t]{2}{*}{$\mathrm{O}$} & \multirow{2}{*}{$\mathrm{P}$} & \multicolumn{2}{|c|}{$\begin{array}{l}\text { Amylase Activity (U/ml) } \\
\text { (mol } \mathrm{H}_{2} / \text { mol glucose) }\end{array}$} \\
\hline & & & & & & & & & & & & & & & & Exp. & Pred. \\
\hline 1 & -1 & 1 & 1 & -1 & 1 & 1 & -1 & -1 & -1 & -1 & 1 & -1 & 1 & -1 & 1 & 9.60 & 9.647 \\
\hline 2 & 1 & 1 & -1 & -1 & -1 & -1 & 1 & -1 & 1 & -1 & 1 & 1 & 1 & 1 & -1 & 9.87 & 9.837 \\
\hline 3 & 1 & 1 & 1 & 1 & -1 & -1 & 1 & 1 & -1 & 1 & 1 & -1 & -1 & -1 & -1 & 8.93 & 8.877 \\
\hline 4 & 1 & -1 & 1 & 1 & 1 & 1 & -1 & -1 & 1 & 1 & -1 & 1 & 1 & -1 & -1 & 4.62 & 4.487 \\
\hline 5 & -1 & 1 & -1 & 1 & 1 & 1 & 1 & -1 & -1 & 1 & 1 & -1 & 1 & 1 & -1 & 9.15 & 9.103 \\
\hline 6 & 1 & 1 & -1 & -1 & 1 & 1 & -1 & 1 & 1 & -1 & -1 & -1 & -1 & 1 & -1 & 7.98 & 7.669 \\
\hline 7 & 1 & 1 & -1 & 1 & 1 & -1 & -1 & -1 & -1 & 1 & -1 & 1 & -1 & 1 & 1 & 4.62 & 5.011 \\
\hline 8 & -1 & -1 & 1 & -1 & 1 & -1 & 1 & 1 & 1 & 1 & -1 & -1 & 1 & 1 & -1 & 9.65 & 10.041 \\
\hline 9 & 1 & -1 & -1 & 1 & 1 & -1 & 1 & 1 & -1 & -1 & -1 & -1 & 1 & -1 & 1 & 4.63 & 4.339 \\
\hline 10 & -1 & -1 & -1 & 1 & -1 & 1 & -1 & 1 & 1 & 1 & 1 & -1 & -1 & 1 & 1 & 7.54 & 7.507 \\
\hline 11 & 1 & -1 & 1 & 1 & -1 & -1 & -1 & -1 & 1 & -1 & 1 & -1 & 1 & 1 & 1 & 5.97 & 6.003 \\
\hline 12 & -1 & -1 & -1 & -1 & -1 & -1 & -1 & -1 & -1 & -1 & -1 & -1 & -1 & -1 & -1 & 9.03 & 9.241 \\
\hline 13 & -1 & 1 & -1 & 1 & -1 & 1 & 1 & 1 & 1 & -1 & -1 & 1 & 1 & -1 & 1 & 7.98 & 8.271 \\
\hline 14 & -1 & -1 & -1 & -1 & 1 & -1 & 1 & -1 & 1 & 1 & 1 & 1 & -1 & -1 & 1 & 9.80 & 9.489 \\
\hline 15 & -1 & 1 & 1 & -1 & -1 & -1 & -1 & 1 & -1 & 1 & -1 & 1 & 1 & 1 & 1 & 10.17 & 9.779 \\
\hline 16 & -1 & 1 & 1 & 1 & 1 & -1 & -1 & 1 & 1 & -1 & 1 & 1 & -1 & -1 & -1 & 8.73 & 8.783 \\
\hline 17 & -1 & -1 & 1 & 1 & -1 & 1 & 1 & -1 & -1 & -1 & -1 & 1 & -1 & 1 & -1 & 8.43 & 8.219 \\
\hline 18 & 1 & 1 & 1 & -1 & -1 & 1 & 1 & -1 & 1 & 1 & -1 & -1 & -1 & -1 & 1 & 9.79 & 9.843 \\
\hline 19 & 1 & -1 & 1 & -1 & 1 & 1 & 1 & 1 & -1 & -1 & 1 & 1 & -1 & 1 & 1 & 6.72 & 6.931 \\
\hline 20 & 1 & -1 & -1 & -1 & -1 & 1 & -1 & 1 & -1 & 1 & 1 & 1 & 1 & -1 & -1 & 6.49 & 6.623 \\
\hline
\end{tabular}

Journal of Experimental Biology and Agricultural Sciences http://www.jebas.org 
Table 3 Estimated effects and coefficients of the Plackett-Burman design for A. oryzae MTCC-8624 utilizing rice bran

\begin{tabular}{|ccccccc|}
\hline Terms & Effect & Coeffi. & SE Coeffi. & T & 71.19 & 0.000 \\
\hline Constant & & 7.985 & 0.1122 & -9.12 & 0.001 \\
\hline A & -2.046 & -1.023 & 0.1122 & 6.21 & 0.003 \\
\hline B & 1.394 & 0.697 & 0.1122 & 2.46 & -8.25 & 0.070 \\
\hline C & 0.552 & 0.276 & 0.1122 & -3.88 & 0.018 \\
\hline D & -1.850 & -0.925 & 0.1122 & -1.38 & 0.239 \\
\hline E & -0.870 & -0.435 & 0.1122 & 4.55 & 0.010 \\
\hline F & -0.310 & -0.155 & 0.1122 & -0.92 & 0.410 \\
\hline G & 1.020 & 0.510 & 0.1122 & 1.85 & 0.137 \\
\hline H & -0.206 & -0.103 & 0.1122 & 0.81 & 0.463 \\
\hline J & 0.416 & 0.208 & 0.1122 & 2.63 & 0.058 \\
\hline K & 0.182 & 0.091 & 0.1122 & -2.16 & 0.097 \\
\hline L & 0.590 & 0.295 & 0.1122 & -1.53 & 0.200 \\
\hline M & -0.484 & -0.242 & 0.1122 & 0.22 & -2.70 \\
\hline N & -0.344 & -0.172 & 0.1122 & 0.835 \\
\hline O & 0.050 & 0.025 & 0.1122 & 0.054 \\
\hline P & -0.606 & -0.303 & & & \\
\hline
\end{tabular}

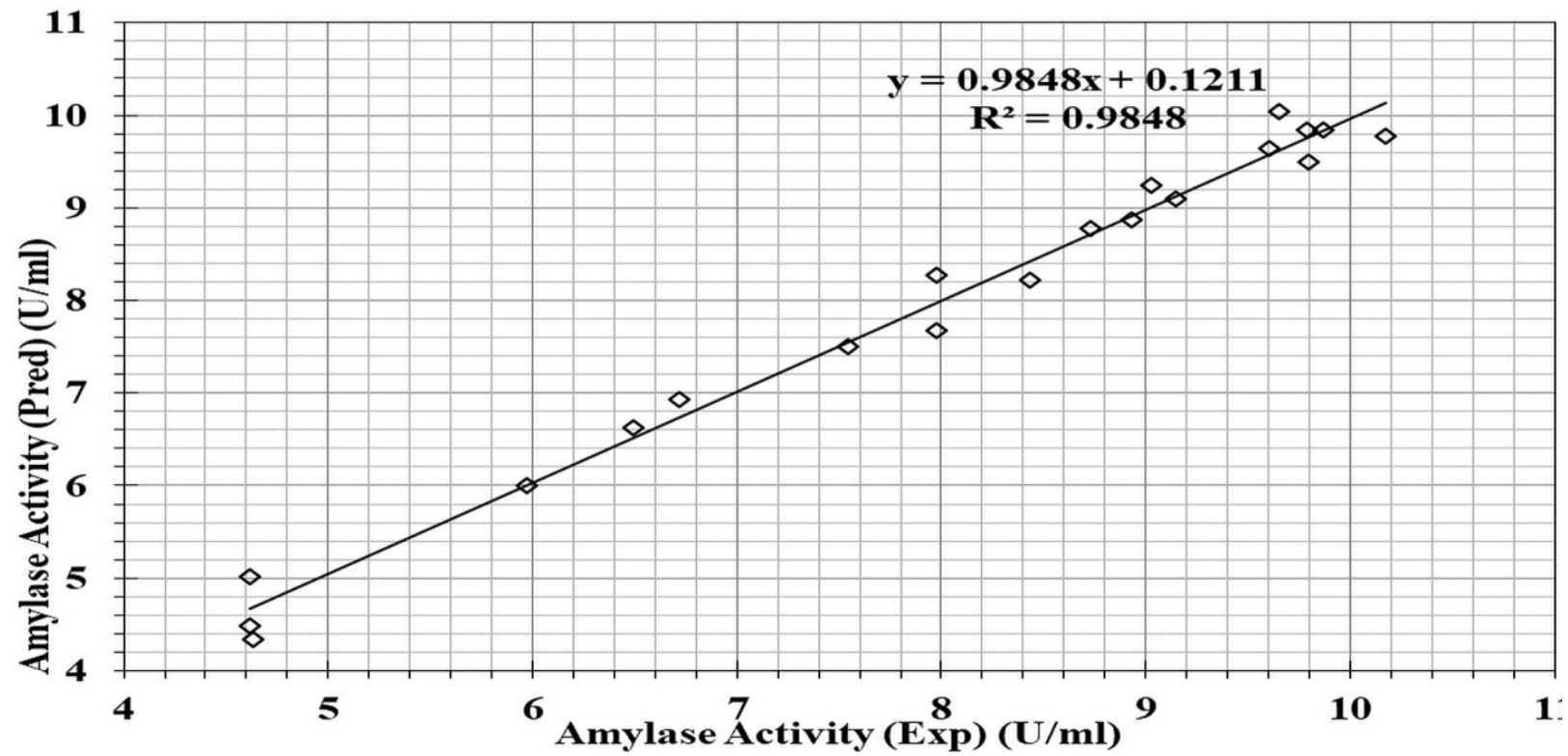

Figure 2 Parity plot between the experimental and predicted values of important variables for A. oryzae MTCC-8624 utilizing rice bran

the enzyme activity is found by analyzing the responses statistically. Variables with $\mathrm{P}$ value $<0.05$ are significant. The effect estimates of amylase activity from the result of PlackettBurman design for rice bran utilizing A. oryzae MTCC-8624 was represented in Table 3 . The Parity plot between the experimental and predicted values is shown in Figure 2 Figure 3 shows the Pareto chart for rice bran. From the Pareto chart $\mathrm{KH}_{2} \mathrm{PO}_{4},\left(\mathrm{NH}_{4}\right)_{2} \mathrm{SO}_{4}, \mathrm{MgSO}_{4}, \mathrm{CaCl}_{2}$ and $\mathrm{FeSO}_{4}$ were found to be significant. It is reached based on the $\mathrm{p}$ values noted in Table 3. 


\section{Pareto Chart of the Stanndardized Effects (responnse is C20, Alpha $=\mathbf{0 . 0 5}$ )}

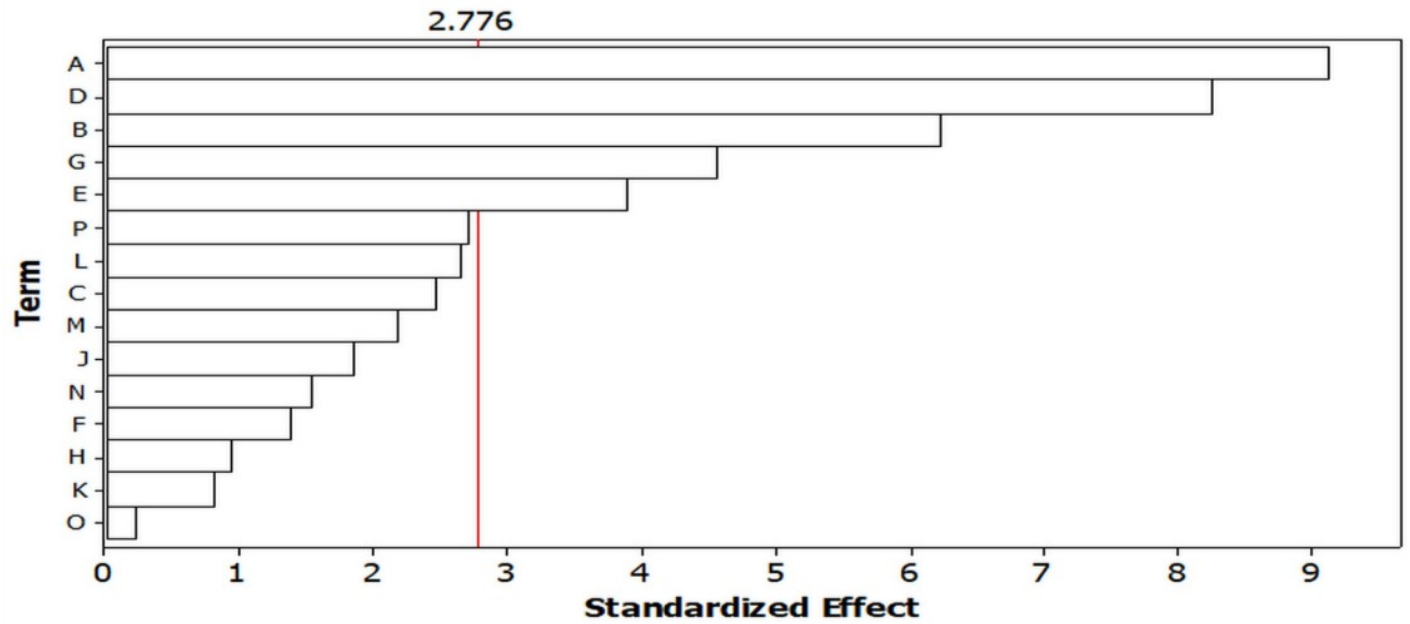

Figure 3 Pareto chart showing the effect of media components on amylase production using $A$. oryzae MTCC-8624 utilizing rice bran

Table 4 Actual and coded values employed in CCD for media optimization of $A$. oryzae MTCC-8624 utilizing rice bran as substrate

\begin{tabular}{|c|c|c|c|c|c|c|c|}
\hline & \multicolumn{2}{c}{ Symbols } & -2.38 & -1 & 0 & +1 & +2.38 \\
\hline $\left.\mathrm{KH}_{2} \mathrm{PO}_{4}, \mathrm{~g} / \mathrm{L}\right)$ & $\mathrm{A}$ & 1 & 2 & 3 & 4 & 5 \\
\hline$\left.\left(\mathrm{NH}_{4}\right)_{2} \mathrm{SO}_{4}, \mathrm{~g} / \mathrm{L}\right)$ & $\mathrm{B}$ & 1 & 3 & 5 & 7 & 9 \\
\hline $\left.\mathrm{MgSO}_{4}, \mathrm{~g} / \mathrm{L}\right)$ & $\mathrm{C}$ & 0.5 & 1 & 1.5 & 2 & 2.5 \\
\hline $\mathrm{CaCl}_{2},(\mathrm{~g} / \mathrm{L})$ & $\mathrm{D}$ & 0.1 & 0.3 & 0.5 & 0.7 & 0.9 \\
\hline $\left.\mathrm{FeSO}_{4}, \mathrm{~g} / \mathrm{L}\right)$ & $\mathrm{E}$ & 0.1 & 0.3 & 0.5 & 0.7 & 0.9 \\
\hline
\end{tabular}

3.2 Optimization of media composition of Aspergillus oryzae MTCC-8624 using CCD for rice bran

The optimum levels of significant variables obtained from the PlackettBurman design for A. oryzae MTCC-8624 is determined by the central composite design of RSM. Table 1 gives the detail of the actual and coded values employed in the design for the substrate rice bran. The 52 run design matrixes using the five independent variables with the experimental and predicted responses are shown in Table 2 . The secondorder polynomial Equation 2 for amylase production (Y) for A. oryzae MTCC-8624 utilizing rice bran as substrate was found as follows:

$$
\begin{array}{rl}
Y=13.5532+0 & 0420755 A-0.00609608 B+0.248739 C \\
& +0.273624 D-0.166398 E \\
& -0.648658 A 2-0.241188 B 2 \\
& -0.596509 C 2-0.341067 D 2 \\
& -0.500166 E 2-0.279688 A B \\
& +0.199062 A C-0.212813 A D \\
& +0.300938 A E+0.369063 B C \\
& +0.134063 B D-0.154063 B E \\
& -0.0209375 C D-0.170313 C E \\
& +0.252188 D E--\rightarrow(2)
\end{array}
$$

Where $\mathrm{A}-\mathrm{KH}_{2} \mathrm{PO}_{4} ; \mathrm{B}-\left(\mathrm{NH}_{4}\right)_{2} \mathrm{SO}_{4} ; \mathrm{C}-\mathrm{MgSO}_{4} ; \mathrm{D}-\mathrm{CaCl}_{2}$ and $\mathrm{E}$ $-\mathrm{FeSO}_{4}$

The parameters estimated and the corresponding $\mathrm{P}$-values are shown in Table 3. From the data the terms A, D, E, B $\mathrm{B}^{2}, \mathrm{C}^{2}, \mathrm{D}^{2}, \mathrm{E}^{2}$, $\mathrm{AB}, \mathrm{AC}, \mathrm{AE}, \mathrm{BC}, \mathrm{BE}$, and $\mathrm{DE}$ were found to be significant for rice bran. Here the $\mathrm{R}^{2}$ values of 0.9833 indicate a good agreement between the experimental and predicted values for rice bran. The $\mathrm{R}^{2}$ predicted values of 0.9353 were also in good agreement with $\mathrm{R}^{2}$ adjusted values of 0.9725 correspondingly. The parity rice bran is represented in Figure 4.

For rice bran, the minimum and maximum production was 10.41 $\mathrm{U} / \mathrm{ml}$ and $14.71 \mathrm{U} / \mathrm{ml}$ respectively for Run No. 25 and Run No. 49. The results obtained by CCD are analyzed by standard analysis of variance (ANOVA) are shown in Table 4. The central composite experimental design with five independent variables for media optimization of A.oryzae MTCC-8624 utilizing rice bran as a substrate is shown in Table 5 .

The three-dimensional response surface curves constructed by the regression model are shown in Figure 5.1 to 5.10 for rice bran. The 


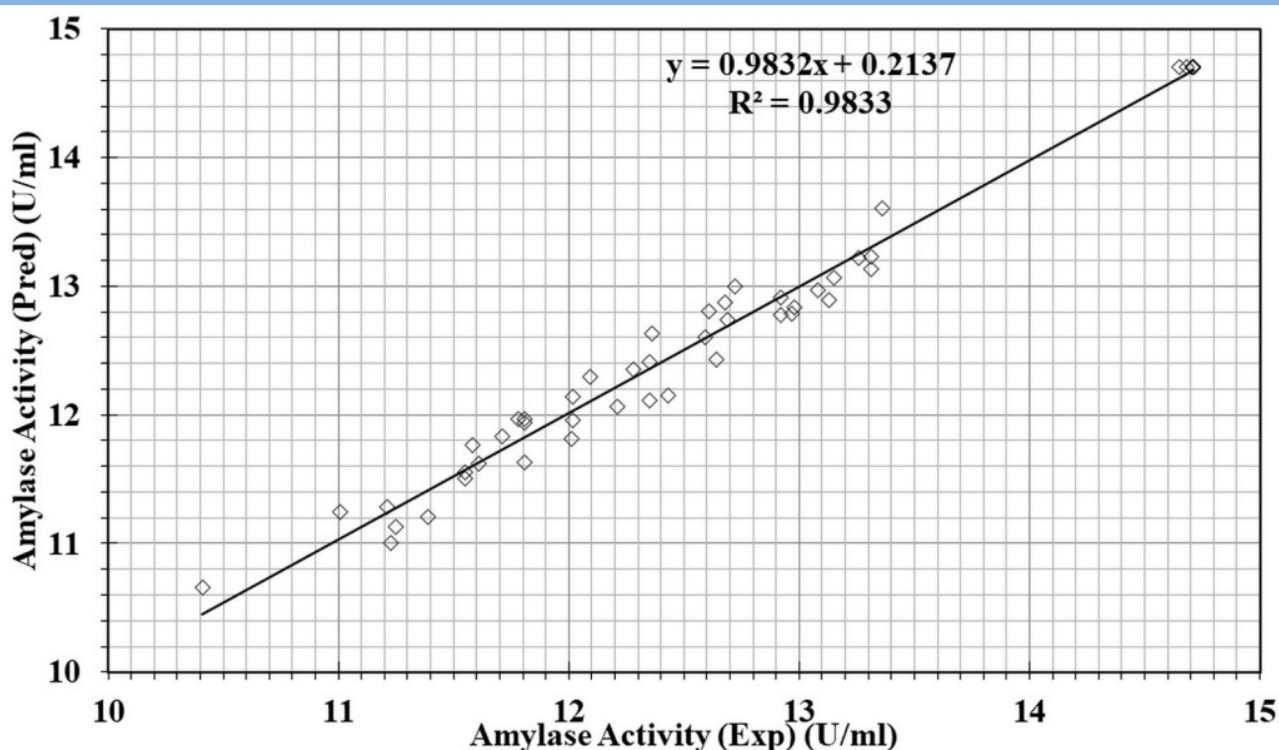

Figure 4 Parity plot between the experimental and predicted values of important variables for $A$. oryzae MTCC-8624 utilizing rice bran

Table 5 The Central Composite experimental design with five independent variables for media optimization of $A$ oryzae MTCC-8624 utilizing rice bran as substrate

\begin{tabular}{|c|c|c|c|c|c|c|c|}
\hline \multirow{2}{*}{ Run No } & \multicolumn{5}{|c|}{ Coded Values } & \multicolumn{2}{|c|}{ Amylase Activity (U/ml) } \\
\hline & A & $\mathrm{B}$ & $\mathrm{C}$ & $\mathrm{D}$ & $\mathrm{E}$ & Exp. & Pred. \\
\hline 1 & 0 & 0 & 0 & 0 & 0 & 14.71 & 14.701 \\
\hline 2 & 1 & 1 & 1 & 1 & -1 & 12.09 & 12.296 \\
\hline 3 & -1 & -1 & -1 & 1 & -1 & 13.31 & 13.232 \\
\hline 4 & 0 & 0 & 0 & 0 & -2.38 & 11.23 & 11.004 \\
\hline 5 & 0 & 0 & 0 & 0 & 2.38 & 11.01 & 11.243 \\
\hline 6 & -1 & 1 & -1 & 1 & 1 & 12.98 & 12.832 \\
\hline 7 & 0 & 0 & 0 & 2.38 & 0 & 13.26 & 13.221 \\
\hline 8 & -1 & -1 & -1 & 1 & 1 & 13.08 & 12.972 \\
\hline 9 & 1 & -1 & 1 & -1 & 1 & 12.92 & 12.916 \\
\hline 10 & 2.38 & 0 & 0 & 0 & 0 & 12.97 & 12.788 \\
\hline 11 & -1 & -1 & 1 & 1 & 1 & 11.21 & 11.286 \\
\hline 12 & 0 & 0 & 0 & 0 & 0 & 14.65 & 14.701 \\
\hline 13 & 0 & 0 & 0 & -2.38 & 0 & 12.69 & 12.736 \\
\hline 14 & 0 & 0 & 0 & 0 & 0 & 14.68 & 14.701 \\
\hline 15 & 1 & 1 & 1 & -1 & -1 & 11.81 & 11.970 \\
\hline 16 & -1 & 1 & 1 & 1 & -1 & 12.59 & 12.605 \\
\hline 17 & 1 & 1 & -1 & 1 & -1 & 11.71 & 11.833 \\
\hline 18 & 1 & -1 & 1 & 1 & 1 & 12.92 & 12.780 \\
\hline 19 & 1 & 1 & -1 & 1 & 1 & 12.02 & 11.959 \\
\hline
\end{tabular}

Journal of Experimental Biology and Agricultural Sciences http://www.jebas.org 


\begin{tabular}{|c|c|c|c|c|c|c|c|}
\hline \multirow{2}{*}{ Run No } & \multicolumn{5}{|c|}{ Coded Values } & \multicolumn{2}{|c|}{ Amylase Activity (U/ml) } \\
\hline & A & B & $\mathrm{C}$ & $\mathrm{D}$ & $\mathrm{E}$ & Exp. & Pred. \\
\hline 20 & -1 & 1 & 1 & -1 & 1 & 11.61 & 11.624 \\
\hline 21 & -1 & -1 & -1 & -1 & 1 & 13.13 & 12.891 \\
\hline 22 & 1 & 1 & 1 & -1 & 1 & 12.64 & 12.430 \\
\hline 23 & -1 & -1 & 1 & -1 & -1 & 11.25 & 11.134 \\
\hline 24 & 1 & 1 & -1 & -1 & -1 & 11.55 & 11.502 \\
\hline 25 & 0 & 0 & 2.38 & 0 & 0 & 10.41 & 10.659 \\
\hline 26 & 0 & 0 & 0 & 0 & 0 & 14.71 & 14.701 \\
\hline 27 & 0 & -2.38 & 0 & 0 & 0 & 11.58 & 11.763 \\
\hline 28 & 0 & 0 & -2.38 & 0 & 0 & 12.35 & 12.108 \\
\hline 29 & 1 & -1 & -1 & 1 & 1 & 12.72 & 12.999 \\
\hline 30 & 1 & -1 & -1 & 1 & -1 & 12.28 & 12.356 \\
\hline 31 & 0 & 0 & 0 & 0 & 0 & 14.71 & 14.701 \\
\hline 32 & -1 & 1 & -1 & 1 & -1 & 13.36 & 13.609 \\
\hline 33 & -1 & 1 & 1 & 1 & 1 & 12.01 & 11.818 \\
\hline 34 & -1 & 1 & 1 & -1 & -1 & 12.21 & 12.066 \\
\hline 35 & 1 & -1 & 1 & -1 & -1 & 11.81 & 11.938 \\
\hline 36 & -1 & -1 & 1 & 1 & -1 & 11.55 & 11.555 \\
\hline 37 & 0 & 0 & 0 & 0 & 0 & 14.71 & 14.701 \\
\hline 38 & 1 & 1 & 1 & 1 & 1 & 12.35 & 12.412 \\
\hline 39 & 0 & 0 & 0 & 0 & 0 & 14.71 & 14.701 \\
\hline 40 & 1 & -1 & -1 & -1 & -1 & 12.02 & 12.142 \\
\hline 41 & 0 & 2.38 & 0 & 0 & 0 & 11.81 & 11.634 \\
\hline 42 & 1 & -1 & 1 & 1 & -1 & 12.43 & 12.147 \\
\hline 43 & 1 & -1 & -1 & -1 & 1 & 13.31 & 13.130 \\
\hline 44 & -1 & 1 & -1 & -1 & -1 & 13.15 & 13.065 \\
\hline 45 & -1 & -1 & 1 & -1 & 1 & 11.39 & 11.209 \\
\hline 46 & -1 & -1 & -1 & -1 & -1 & 12.61 & 12.805 \\
\hline 47 & -1 & 1 & -1 & -1 & 1 & 12.36 & 12.633 \\
\hline 48 & -2.38 & 0 & 0 & 0 & 0 & 12.68 & 12.870 \\
\hline 49 & 0 & 0 & 0 & 0 & 0 & 14.71 & 14.701 \\
\hline 50 & 0 & 0 & 0 & 0 & 0 & 14.71 & 14.701 \\
\hline 51 & 0 & 0 & 0 & 0 & 0 & 14.71 & 14.701 \\
\hline 52 & 1 & 1 & -1 & -1 & 1 & 11.78 & 11.972 \\
\hline
\end{tabular}




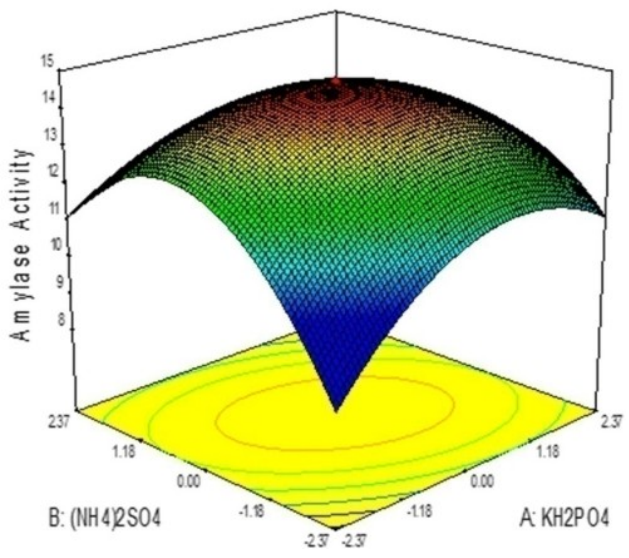

Figure 5.1 3D Plot shows the interaction between the medium components (NH4)2SO4 and $\mathrm{KH} 2 \mathrm{PO} 4$ for Aspergillus oryzae using rice bran

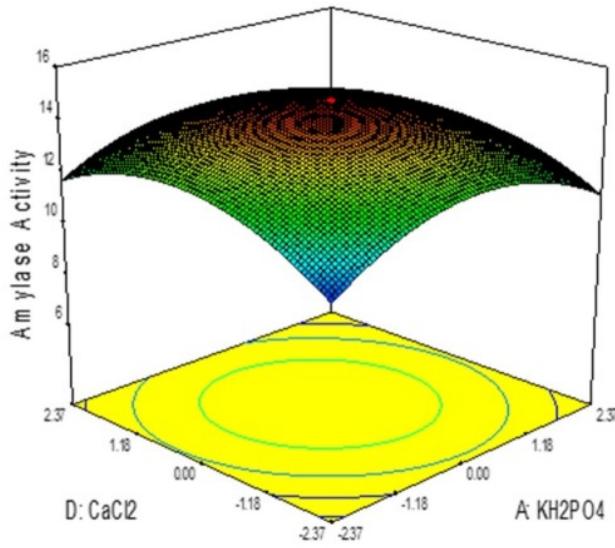

Figure 5.3 3D Plot shows the interaction between the medium components $\mathrm{CaCl}_{2}$ and $\mathrm{KH}_{2} \mathrm{PO}_{4}$ for Aspergillus oryzae using rice bran

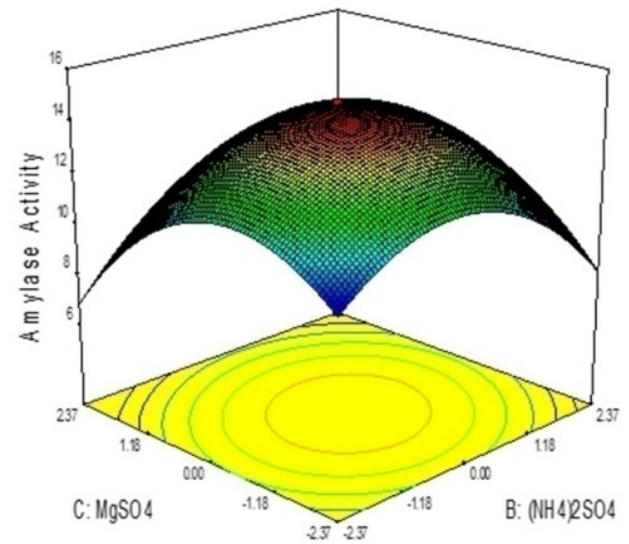

Figure 5.5 3D Plot shows the interaction between the medium components $\left(\mathrm{NH}_{4}\right)_{2} \mathrm{SO}_{4}$ and $\mathrm{MgSO}_{4}$ for Aspergillus oryzae using rice bran

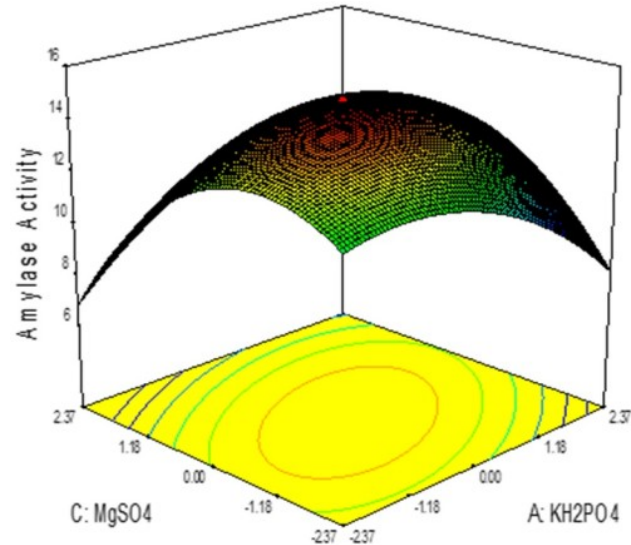

Figure 5.2 3D Plot shows the interaction between the medium components $\mathrm{MgSO} 4$ and $\mathrm{KH} 2 \mathrm{PO} 4$ for

Aspergillus oryzae using rice bran

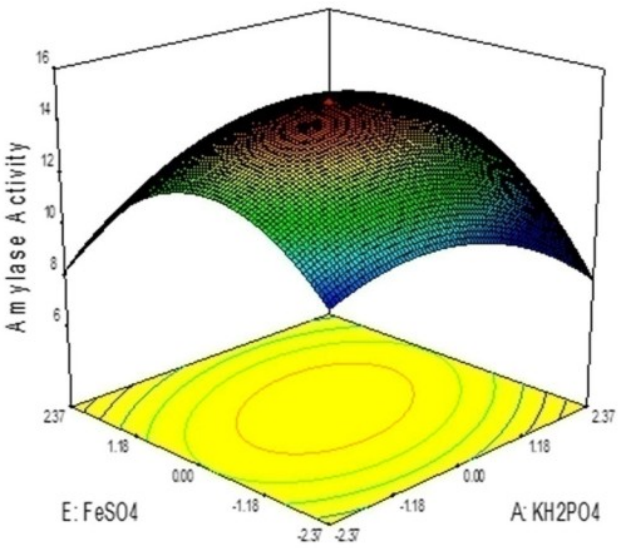

Figure 5.4 3D Plot shows the interaction between the medium components $\mathrm{FeSO}_{4}$ and $\mathrm{KH}_{2} \mathrm{PO}_{4}$ for Aspergillus oryzae using rice bran

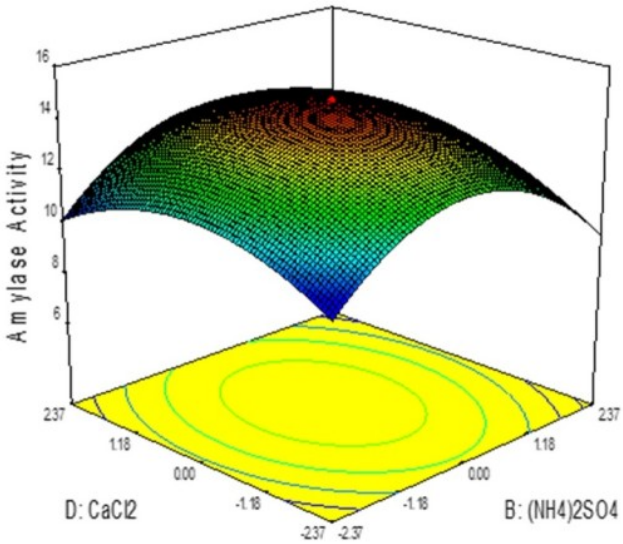

Figure 5.6 3D Plot shows the interaction between the medium components $\left(\mathrm{NH}_{4}\right)_{2} \mathrm{SO}_{4}$ and $\mathrm{CaCl}_{2}$ for Aspergillus oryzae using rice bran

Journal of Experimental Biology and Agricultural Sciences http://www.jebas.org 


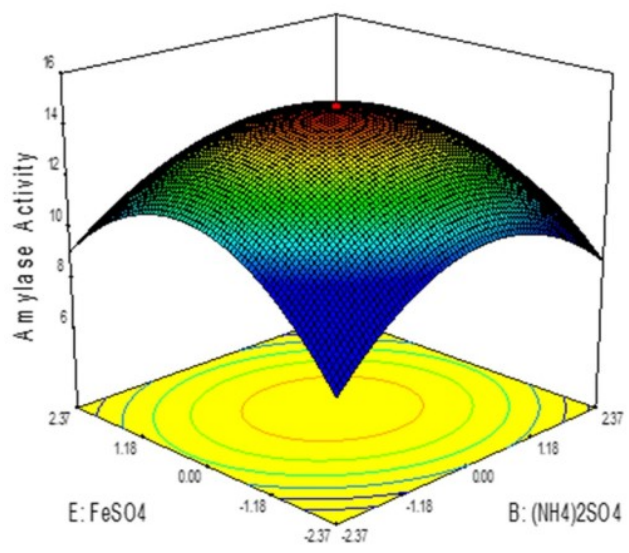

Figure 5.7 3D Plot shows the interaction between the medium components $\left(\mathrm{NH}_{4}\right)_{2} \mathrm{SO}_{4}$ and $\mathrm{FeSO}_{4}$ for Aspergillus oryzae using rice bran

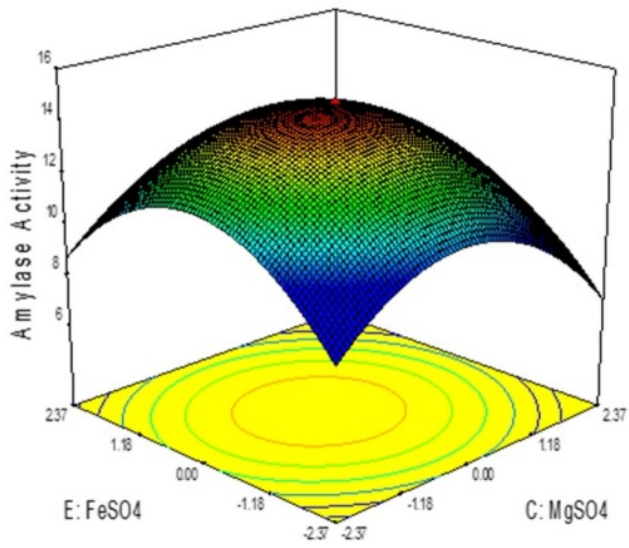

Figure 5.9 3D Plot shows the interaction between the medium components $\mathrm{FeSO}_{4}$ and $\mathrm{MgSO}_{4}$ for Aspergillus oryzae using rice bran

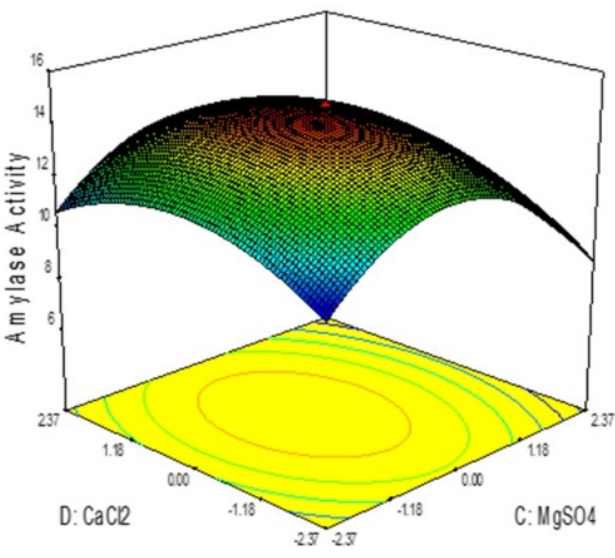

Figure 5.8 3D Plot shows the interaction between the medium components $\mathrm{MgSO}_{4}$ and $\mathrm{CaCl}_{2}$ for Aspergillus oryzae using rice bran

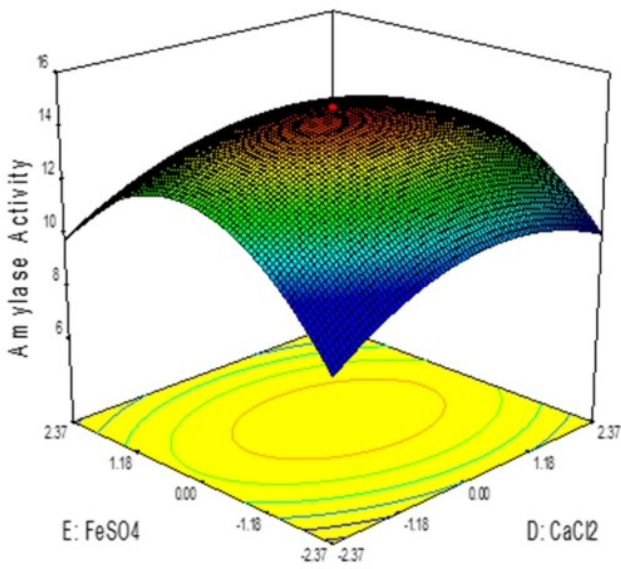

Figure 5.10 3D Plot shows the interaction between the medium components $\mathrm{CaCl}_{2}$ and $\mathrm{FeSO}_{4}$ for Aspergillus oryzae using rice bran optimum values of the variables were found from the equations derived by the differentiation of the obtained second-order polynomial equations. The optimum values were found to be $\mathrm{KH}_{2} \mathrm{PO}_{4}-2.69(\mathrm{~g} / \mathrm{L}) ;\left(\mathrm{NH}_{4}\right)_{2} \mathrm{SO}_{4}-4.95(\mathrm{~g} / \mathrm{L}) ; \mathrm{MgSO}_{4}-1.70(\mathrm{~g} / \mathrm{L})$; $\mathrm{CaCl}_{2}-0.53(\mathrm{~g} / \mathrm{L})$ and $\mathrm{FeSO}_{4}-0.50(\mathrm{~g} / \mathrm{L})$ for rice bran shown in Table 5. Table 6 shows the results of the regression analysis of the second-order polynomial model for media optimization of $A$. oryzae MTCC-8624 utilizing rice bran as a substrate. The ANOVA for the fitted polynomial model for media optimization of $A$. oryzae MTCC-8624 utilizing rice bran as the substrate is shown in Table 7. The optimum values were found to be $\mathrm{KH}_{2} \mathrm{PO}_{4}-2.69(\mathrm{~g} / \mathrm{L})$ $\left(\mathrm{NH}_{4}\right)_{2} \mathrm{SO}_{4}-4.95(\mathrm{~g} / \mathrm{L}) ; \mathrm{MgSO}_{4}-1.70(\mathrm{~g} / \mathrm{L}) ; \mathrm{CaCl}_{2}-0.53(\mathrm{~g} / \mathrm{L})$ and $\mathrm{FeSO}_{4}-0.50(\mathrm{~g} / \mathrm{L})$ for rice bran and the same is reported in Table 8. Results of the studyrevealed that rice bran can be use as an suitable and cost-effective substratefor alpha-amylase production, these results are in agreement with the findings of previous researchers such as Konsula \& Liakopoulou-Kyriakides (2004), Shivaramakrishnam et al. (2006), Bharathiraja et al. (2016), Subash et al. (2017)and Asrat \& Girma (2018)

\section{Conclusion}

This investigation concludes that the optimization of mineral supplements for the fermentative $\alpha$-amylase production and its suitability for a large-scale production using cheap and easily available substrate rice. The fungal strain A. oryzae MTCC-8624 is used in this study to investigate the $\alpha$-amylase production capability. The significant media components identified by Plackett-Burman design are $\mathrm{KH}_{2} \mathrm{PO}_{4}=2.69 \mathrm{~g} / \mathrm{L} ; \mathrm{MgSO}_{4}=1.70 \mathrm{~g} / \mathrm{L} ; \mathrm{CaCl}_{2}=0.53 \mathrm{~g} / \mathrm{L}$; $\mathrm{FeSO}_{4}=0.5 \mathrm{~g} / \mathrm{L}$ and $\left(\mathrm{NH}_{4}\right)_{2} \mathrm{SO}_{4}=4.95 \mathrm{~g} / \mathrm{L}$ for rice bran. 
Table 6 Results of the regression analysis of second order polynomial model for media optimization of $A$. oryzae MTCC-8624 utilizing rice bran as substrate

\begin{tabular}{|c|c|c|c|}
\hline Term constant & Regression coefficient & T-statistics & P-value \\
\hline Intercept & 14.7015 & 240.049 & 0.000 \\
\hline A & -0.0173 & -0.585 & 0.000 \\
\hline B & -0.0271 & -0.915 & 0.563 \\
\hline $\mathrm{C}$ & -0.3046 & -10.288 & 0.367 \\
\hline $\mathrm{D}$ & 0.1019 & 3.443 & 0.000 \\
\hline E & 0.0503 & 1.697 & 0.002 \\
\hline $\mathrm{A}^{2}$ & -0.3311 & -12.997 & 0.100 \\
\hline $\mathrm{B}^{2}$ & -0.5308 & -20.84 & 0.000 \\
\hline $\mathrm{C}^{2}$ & -0.5865 & -23.026 & 0.000 \\
\hline $\mathrm{D}^{2}$ & -0.3045 & -11.956 & 0.000 \\
\hline$E^{2}$ & -0.6325 & -24.83 & 0.000 \\
\hline A.B & -0.225 & -6.532 & 0.000 \\
\hline A.C & 0.3669 & 10.651 & 0.000 \\
\hline A.D & -0.0531 & -1.542 & 0.133 \\
\hline A.E & 0.2256 & 6.55 & 0.000 \\
\hline B.C & 0.1681 & 4.881 & 0.000 \\
\hline B.D & 0.0294 & 0.853 & 0.400 \\
\hline B.E & -0.1294 & -3.756 & 0.001 \\
\hline C.D & -0.0013 & -0.036 & 0.971 \\
\hline C.E & -0.0025 & -0.073 & 0.943 \\
\hline D.E & -0.0863 & -2.504 & 0.018 \\
\hline
\end{tabular}

$R-S q=98.33 \% R-S q($ pred $)=93.53 \% R-S q($ adj $)=97.25 \%$

Table 7 ANOVA for the fitted polynomial model for media optimization of A. oryzae MTCC-8624 utilizing rice bran as substrate

\begin{tabular}{|cccccc|}
\hline Sources of variation & Sum of squares & Degrees of freedom (DF) & Mean square (MS) & F- value & P-value \\
\hline Regression & 69.3666 & 20 & 3.4683 & 91.34 & 0.000 \\
\hline Linear & 4.6235 & 5 & 0.9247 & 24.35 & 0.000 \\
\hline Square & 55.3906 & 5 & 11.0781 & 291.76 & 0.000 \\
\hline Interaction & 9.3525 & 10 & 0.9352 & 24.63 & 0.000 \\
\hline Residual Error & 1.1771 & 31 & 0.038 & - \\
\hline Lack-of-Fit & 1.1734 & 22 & 0.0533 & 130.09 & 0.000 \\
\hline Pure Error & 0.0037 & 9 & 0.0004 & - & - \\
\hline Total & 70.5437 & 51 & - & - \\
\hline
\end{tabular}

Table 8 Optimum values of the media components obtained from regression equation for A. oryzae MTCC-8624 utilizing rice bran as substrate

\begin{tabular}{|ccc|}
\hline Independent variables & Optimum value (coded) & Optimum value (real) $(\mathrm{g} / \mathrm{L})$ \\
\hline $\mathrm{KH}_{2} \mathrm{PO}_{4},(\mathrm{~g} / \mathrm{L})$ & -0.31231 & 2.69 \\
\hline$\left(\mathrm{NH}_{4}\right)_{2} \mathrm{SO}_{4},(\mathrm{~g} / \mathrm{L})$ & -0.02402 & 4.95 \\
\hline $\mathrm{MgSO}_{4},(\mathrm{~g} / \mathrm{L})$ & 0.40841 & 1.70 \\
\hline $\mathrm{CaCl}_{2},(\mathrm{~g} / \mathrm{L})$ & 0.16817 & 0.53 \\
\hline $\left.\mathrm{FeSO}_{4}, \mathrm{~g} / \mathrm{L}\right)$ & 0.02402 & 0.50 \\
\hline
\end{tabular}

Journal of Experimental Biology and Agricultural Sciences

http://www.jebas.org 


\section{Conflict of Interest}

The authors declare that there is no conflict of interests regarding the publication of this paper.

\section{Acknowledgements}

The authors wish to express their sincere gratitude for the support extended by the authorities of Annamalai University, Annamalai Nagar, Tamil Nadu, India in carrying out the research work in Bioprocess Laboratory, Department of Chemical Engineering, Faculty of Engineering and Technology, Annamalai University.

\section{References}

Ahmed K, Valeem EE, Khan MA, Uul-Haq Q (2015) Biosynthesis of alpha amylase from aspergillus fumigatus (fresenius 1863) in submerged fermentation. Pakistan Journal of Biotechnology 12(2): 87 - 92.

Ahuja SK, Ferreira GM, Morreira AR (2004) Application of Plackett and Burman design and response surface methodology to achieve exponential growth of aggregated shipworm bacterium. Biotechnology and Bioengineering 85: 666-675.

Asrat B, Girma A (2018) Isolation, production and characterization of amylase enzyme using the isolate Aspergillus niger FAB-211. International Journal of Biotechnology and Molecular Biology Research 9(2): 7-14

Avwioroko OJ, Tonukari NJ (2015) Biochemical characterization of crude $\alpha$-amylase of Aspergillus spp. associated with the spoilage of cassava (Manihot esculenta) tubers and processed products in Nigeria. Advances in Biochemistry 3:15-23

Bharathiraja B, Jayakumar M, Nithyananthi MJT, Vinosh Muthu kumar P, Saravanaraj A, Senthilkumar K (2016) Production and kinetics of amylase from starch using mutant strain of Bacillus $\mathrm{Sp}$ MTCC 1434. Journal of Chemical and Pharmaceutical Sciences 9(1): $281-286$.

Demirkan E, Sevgi T, Baskurt M (2017) Optimization of Physical Factors Affecting the Production of the $\alpha$-Amylase from a Newly Isolated Bacillus sp. M10 Strain. Karaelmas Science and Engineering Journal 7(1):23-30

Ellaiah P, Adinarayana K, Bhavani Y, Padmaja P, Srinivasulu B (2002) Optimization of process parameters for glucoamylase production under solid state fermentation by a new isolated Aspergillus species. Process Biochemistry 38: 615-620.

Elmansy EA, Asker MS, El-Kady EM, Hassanein SM, El-Beih FM (2018) Production and optimization of $\alpha$-amylase from thermohalophilic bacteria isolated from different local marine environments. Bulletin of the National Research Centre 42:31
Fogarty WM (1983) Microbial Amylases. In: Microbial Enzymes and Biotechnology, W.M. Fogarty (Ed.). Applied Science Publishers Ltd., London, UK, 1-92

Jiby JM, Prem JV, Sajeshkumar NK, Anjaly A (2016) Amylase production by Aspergillus niger through submerged fermentation using starchy food by-products as substrate. International Journal of Herbal Medicine 4(6): 34-40.

Konsula Z, Liakopoulou-Kyriakides M (2004) Hydrolysis of starches by the action of an $\alpha$-amylase from Bacillus subtilis. Process Biochemistry 39(11):1745-1749

Mabel SH, Marilu RR, Nelson PG, Renato PR (2006) Amylase production by Aspergillus niger in submerged cultivation on two wastes from food industries. Journal of Food Engineering 73: 93100 .

Pankaj, Bisht TS, Pathak VM, Barh A, Chandra D (2015) Optimization of amylase production from the fungal isolates of Himalayan region Uttarakhand, India. Ecology, Environment and Conservation 21 (3): 1517-1521.

Pathania S, Sharma N, Handa S (2017) Optimization of Culture Conditions for Production of Amylase by Bacillus amyloliquifaciens SH8 Using Response Surface Methodology. Proceedings of the Indian National Science Academy 83(1): 203-210

Rajagopalan G, Krishnan C (2008) a-Amylase production from catabolite derepressed Bacillus subtilis KCC103 utilizing sugarcane bagasse hydrolysate, Bioresource Technology 99: 3044-3050

Sarra M, Redin I, Ochin F (1993) Application of factorial design to the optimization of medium components in batch cultures of Streptomyces lividans TK21 producing a hybrid antibiotic. Biotechnology Letters 15: 559-564.

Shah IJ, Gami PN, Shukla RM, Acharya DK (2014) Optimization for $\alpha$-amylase production by Aspergillus oryzae using submerged fermentation technology. Basic Research Journal of Microbiology 1(4): 01-10.

Shivaramakrishnam S, Gangadharan D, Nampoothiri KM, Soccol CR, Pandey A (2006) $\alpha$-Amylases from microbial sources-an overview on recent developments. Food Technology and Biotechnology 44(2):173-184.

Singhania RR (2011) Chapter 8 - Production of Celluloytic Enzymes for the Hydrolysis of Lignocellulosic Biomass - Biofuels $177-201$

Singhania RR, Patel AK, Thomas L, Goswami M, Giri BS, Pandey A (2015), Chapter 13 - Industrial Enzymes - Industrial Biorefineries \& White Biotechnology, 473-497 
Subash CBG, Periasamy A, MdArshad MK, Thangavel L, Chun HV, UdaHashim, Suresh VC (2017) Biotechnological Processes in Microbial Amylase Production. Article ID 1272193: 1 - 9

Tanyildizi MS, Dursun Ozer D, Elibol M (2005) Optimization of a-amylase production by Bacillus sp. Process Biochemistry
40: $2291-2296$.

Vimal SP, Ujjval BT, Kamlesh CP (2015) A statistical approach for the production of thermostable and alklophilic alpha-amylase from Bacillus amyloliquefaciens KCP2 under solid-state fermentation. 3 Biotech 5:211-220 